\title{
Poesia e composição: considerações sobre uma das "teses" de João Cabral de Melo Neto
}

\author{
Poetry and composition: Considerations about one of the \\ João Cabral de Melo Neto's "theses"
}

\author{
Rodrigo Caldeira* \\ rodrigolcal@gmail.com \\ Universidade Federal do Espírito Santo
}

\begin{abstract}
RESUMO: Mais conhecido por sua obra poética, João Cabral de Melo Neto (19201999) é, também, autor de um valioso material crítico em prosa que, desde a primeira reunião em 1997, tem despertado interesse e contribuído para uma melhor compreensão do seu projeto literário. Destas "teses" - como o próprio autor se referia a alguns desses trabalhos - destacam os três primeiros: "Considerações sobre o poeta dormindo" (1941), "Joan Miró" (1950) e "Poesia e composição" (1952). O propósito deste artigo é, portanto, apresentar algumas considerações acerca do pensamento crítico desenvolvido por Cabral no texto "Poesia e composição", destacando os conceitos originais de "poetas fáceis" e de "poetas difíceis" desenvolvidos pelo autor de modo a contribuir para as discussões sobre este tema. Apoiam esta leitura os trabalhos de Lima (2002), Carvalho (2009), Siscar (2018) e Pessôa (2019).
\end{abstract}

PALAVRAS-CHAVES: João Cabral de Melo Neto. Poesia. Composição. Crítica.

ABSTRACT: Mostly known for his poetry work, João Cabral de Melo Neto (1920-1999) is also, author of a valuable work of criticism, which, since its first collection in 1997, has awaken interest and has also contributed to a better comprehension of his literary project. Out of the "theses" - as the author himself referred to some those works- the first three deserve some highlighting: "Considerações sobre o poeta dormindo" (1941), "Joan Miró" (1950) and "Poesia e composição" (1952). Thus, the purpose of this article is, to present some considerations on the critical thoughts developed by Cabral in the text "Poesia e composição", highlighting the original concepts of "easy poets" and "difficult poets" developed by the author in order to contribute to the discussion about this subject. The works of Lima (2002), Carvalho (2009), Siscar (2018) and Pessôa (2019) support this article.

KEYWORDS: João Cabral de Melo Neto. Poetry. Composition. Criticism.

\footnotetext{
* Mestre em Letras pelo Programa de Pós-Graduação em Letras da Universidade Federal do Espírito Santo. Graduado em História e com Especialização em Estudos Literários pela Universidade Federal do Espírito Santo.
} 


\section{Introdução}

Durante os primeiros anos de sua formação intelectual, João Cabral de Melo Neto cogitou tornar-se crítico. Contudo, considerando que não tinha "cultura nem discernimento" (ATHAYDE, 1998, p. 25) para tal empreitada, se assumiu como poeta, fazendo do ofício sua profissão de fé. No entanto, mesmo sem assumir papel oficial de crítico, Cabral produziu valioso corpus do qual destacam-se os três primeiros: "Considerações sobre o poeta dormindo", "Joan Miró" e "Poesia e composição"1.

O primeiro, "Considerações sobre o poeta dormindo", foi apresentado como "tese" ao Congresso de Poesia do Recife (1941), organizado pelo próprio Cabral, e funciona como uma espécie de justificação teórica antecipada ao seu primeiro livro de poemas Pedra do Sono (1942). No segundo, "Joan Miró", o autor discorre sobre a obra do pintor catalão, buscando nele a sua, também, digamos, psicologia da composição. O último trabalho, "Poesia e composição", sobre o qual nos deteremos mais neste artigo, trata-se de uma conferência pronunciada na Biblioteca de São Paulo, em 1952.

André Vinícius Pessôa observa que todo o pendor para análise demonstrado pelo jovem Cabral fez com que ele se tornasse "um poeta-crítico que, ao optar pela 'crítica criadora', incluiu a reflexão no interior de sua obra em versos" e que sua prosa crítica, embora não possua a mesma extensão de outros poetas que lhe foram contemporâneos como Murilo Mendes e Manuel Bandeira, revela um "profícuo teórico" (PESSÔA, 2019, p. 1). Em entrevista de 1981, Cabral definiu assim o que seria, para ele, uma "crítica criadora”: "[...] É raro um sujeito escrever um ensaio

\footnotetext{
1 Estes textos e os demais em prosa de João Cabral foram reunidos, em 1997, pela editora Nova Fronteira no livro Prosa. No início de 2020, ano do centenário de nascimento de João Cabral, a Companhia das Letras anunciou que iria lançar, pelo selo Alfaguara, as reuniões completas da poesia e da prosa do autor. Até o momento, somente o volume Poesia completa, com organização de Antonio Carlos Secchin, foi publicado. Sobre o volume Prosa completa, sabemos que está sendo organizado pelo professor Sérgio Martagão e conta com inéditos achados pela pesquisadora Ednéia Ribeiro. Sobre um destes inéditos, cabe reproduzir trecho da notícia do jornal Correio Brasilense pois, a julgar pelo título e data do trabalho, é bem provável que haja algum diálogo com o "Poesia e composição" apresentado aqui: "Entre os inéditos, descobertos por Ednéia, destaca-se uma conferência de 30 laudas, intitulada A poesia brasileira, escrita no Recife, em 1954, mas nunca publicada, segundo depoimento do próprio poeta no manuscrito, informa Ednéia. Apesar de pesquisas em jornais e em outros documentos da época, não foi possível identificar se houve algum evento no Recife nesse ano, no qual a conferência teria sido apresentada." FRANCISO, Severino. "Nos 100 anos de João Cabral de Melo Neto, livros do poeta serão lançados". In.: Correio Brasiliense. Brasília-DF, 11/01/2020. Disponível em: <https://www.correiobraziliense.com.br/app/noticia/diversao-e- arte/2020/01/11/interna_diversao_ arte,819712/nos-100-anos-de-joao-cabral-de-melo-neto-livros-do-poeta-serao-lancad.shtml> Acesso em: 01 jun. 2021.
} 
espontaneamente, sem ninguém ter pedido. Um sujeito que pensa 'gosto muito do Graciliano', sentar e escrever um livro sobre Graciliano. Essa seria a crítica criadora." (Cf. ATHAYDE, 1998, p. 25)

É, portanto, no encalço desse profícuo teórico que este trabalho pretende apresentar algumas considerações acerca do pensamento crítico desenvolvido por Cabral no texto "Poesia e composição". Destacamos, sobretudo, os conceitos originais de "poetas fáceis" e de "poetas difíceis" criados pelo autor, por acreditar que as preocupações apresentadas, por um poeta como João Cabral, acerca dos dilemas e desafios em torno do processo de composição poética, contribuem, a meu ver, tanto para a crítica literária quanto para os próprios poetas que insistem nesta luta vã.

\section{Poesia e composição}

Em "Poesia e composição", João Cabral, como já fizera em "Considerações sobre o poeta dormindo", procurou sistematizar uma crítica sobre a composição poética que, embora não explícita, justificasse ou, melhor, consolidasse a sua própria produção poética até aquela data e a que estava por vir. O trabalho inicia constatando a dificuldade em se falar de composição, sobretudo para ele que primava pela objetividade. Outra dificuldade, apontava o autor, se dava em razão de que não havia apenas uma ideia do que vinha a ser composição entre os poetas de seu tempo. Para alguns, a composição seria como aprisionar a poesia no poema; para outros, seria o ato de "elaborar a poesia em poema" através das muitas horas de uma procura. Nesse grupo de poetas, para os quais composição é procura, outro aspecto dificultador existente era o de que havia certo pudor em expor as dificuldades enfrentadas na composição do poema, pois sabiam, segundo Cabral, que tal força era "feita de mil fracassos, de truques que ninguém deve saber, de concessões ao fácil, de soluções insatisfatórias, de aceitação resignada do pouco que se é capaz de conseguir e de renúncia ao que, de partida, se desejou conseguir" (MELO NETO, 1997, p. 51).

Já nos poetas da outra família, para quem composição é achado, como consideram que os poemas são de iniciativa da própria poesia, eles pouco têm a dizer sobre o processo de composição. Entretanto, na compreensão de Cabral, estes ainda não são os grandes empecilhos ao estudo da composição. A dificuldade maior residiria na impossibilidade de "generalizar e apresentar um juízo de valor" à literatura moderna. Ou seja, a falta de um conceito de literatura que promovesse certo interesse 
universal, determinado pela exigência dos indivíduos para quem se fazia a literatura, fez com que a crítica se tornasse tão individualista quanto a própria literatura, ou, no rigoroso olhar do poeta pernambucano: "vieram transformá-la no que ela é hoje, antes de tudo - a atividade incompreensiva por excelência" (MELO NETO, 1997, p. 52). Há, nas palavras de Cabral, certo saudosismo de uma época em que havia padrões de julgamentos sobre os quais os críticos poderiam ancorar suas análises, destacando aspectos relacionados à poética, à retórica $\mathrm{e}$, mesmo, à técnica utilizada por determinado autor de modo a validar se sua obra atendeu às normas e que, portanto, estaria mais próxima de "assegurar a satisfação da necessidade" (MELO NETO, 1997, p. 52) do público leitor. A defesa da norma apregoada por Cabral pautava-se, sobretudo, na possibilidade de uma teoria da composição que, não havendo a norma como regra, tornava-se, a seu ver, inconcebível. Cabral denuncia o individualismo da criação poética do seu tempo, no qual cada autor trabalhava "à sua maneira", e que isto fez com que a preocupação de comunicar, antes comum à literatura, fosse substituída pela preocupação de exprimir-se, fato que anulou, segundo ele, o leitor e sua necessidade no momento em que o poeta está realizando a sua composição. Estas parecem ser, portanto, as duas principais preocupações contidas na crítica de Cabral à produção poética dos anos 50 e ao fato de não existir conceitos claros que norteassem o fazer poético, a saber: o leitor e sua necessidade.

Para Luiz Costa Lima (2002, p. 117), João Cabral irá resgatar do romantismo estes "dilemas e características da poesia contemporânea", em que "o problema desta tradição poética parte de que a liberdade expressiva é contrária a regras, afetando ora a qualidade artística do poema ora sua capacidade de comunicação". A consequência dessa, digamos, insubordinação do fazer poético - pautada num individualismo extremo que não tinha como parâmetro nenhuma norma ou regra previamente estabelecida pela "necessidade do leitor" — é que cada poeta passou a ter a sua própria poética, o que resultou, por conseguinte, que cada um, também, criasse suas próprias mitologias, linguagens e leis de composição para, a partir daí, definir o próprio conceito de poema e dele poder estabelecer os conceitos de poesia, de literatura e de arte. No entanto, Cabral alertava, nada obrigava a esses poetas obedecer às regras que antes mesmo criaram, pois o que se espera deles é que não se pareçam a nenhum predecessor e que contribuam, cada um, com uma expressão original. É nesse sentido que Ricardo Souza de Carvalho, reforçando que a conferência "Poesia e composição" é uma continuação das reflexões acerca da criação artística 
apresentadas antes no ensaio sobre o pintor Joan Miró, irá afirmar que Cabral "ao propor o equilíbrio entre a inspiração e o trabalho, não deixa escapar a oportunidade de criticar aqueles - logo ali no público - que fazem a obra para seus pares e não para se comunicar com o leitor" (CARVALHO, 2009, p. 143).

Portanto, pelos motivos expostos e considerando a impossibilidade de uma teoria da composição, de uma "composição representativa do poema moderno", Cabral afirmava ser possível apenas agrupar um par de poemas e poetas somente sob a égide da "impossibilidade de definição", dadas as "inúmeras composições antagônicas que convivem hoje" (MELO NETO, 1997, p. 54). No entanto, não obstante essas dificuldades apontadas pelo autor na sua busca por uma teoria da composição do poema moderno, ele desenvolverá seu raciocínio no sentido de contribuir, senão para a teoria almejada, para uma melhor distinção entre dois métodos de composição que, grosso modo, definiriam e distinguiriam as duas famílias de poetas inicialmente apresentadas. Para Cabral, a "composição literária oscila permanentemente entre dois pontos extremos a que é possível levar as ideias de inspiração e trabalho de arte" (MELO NETO, 1997, p. 54). Com essa definição, ele não pretende opor essas duas ideias, mas sim reafirmar sua teoria de que o objeto final - seja fruto obtido espontaneamente, "como presente dos deuses" (achado); seja elaboração demorada, conquista dos homens (procura) - será sempre uma obra com elementos da experiência de um homem. Cabral não entende que a luta entre essas ideias seja o motor da história literária, mas apenas que, em sendo a composição um domínio extremamente sensível, as transformações que ocorrem na história literária tendem a influenciá-la, sendo que a predominância de uma ideia sobre a outra se determina pelo conjunto de valores de cada época. O que, para Cabral, torna "nossa" época mais original é que nela a

[...] polarização mostra-se maior do que nunca e que, no lugar da preponderância de uma dessas idéias, presenciamos a coexistência de uma infinidade de atitudes intermediárias, organizando-se a partir das posições mais extremas a que já se chegou na história da composição artística. (MELO NETO, 1997, p. 55)

Um elemento importante, continua Cabral, para a compressão dessa época, seria a "psicologia pessoal de cada autor". Em épocas de relativo equilíbrio, nas quais literatura correspondia à uma visão estética comum, o traço psicológico de determinado autor tendia a confundir-se com essa noção. Não sendo, contudo, esse 
o caso para a poesia moderna, em que Cabral identificava duas classes de autores: os fáceis e os difíceis.

Nos primeiros, os fáceis, vinculados à família para quem composição é achado, há uma identificação de facilidade com inspiração; este autor espontâneo, verá com falsidade qualquer trabalho de composição que comprometa o poema original. Para os outros, os difíceis, atrelados à família dos que compreendem composição como procura, "a preocupação formal é uma condição de existência" (MELO NETO, 1997, p. 56) e desconfiam de tudo relacionado à espontaneidade. Cabral destaca que, se em seu tempo estes traços pessoais "têm força suficiente para se constituírem em 'teoria' da composição de seus autores”, noutras épocas, onde a norma regia o fazer poético, tal temperamento apresentava-se "mais ou menos subordinado, mais ou menos dominado" (MELO NETO, 1997, p. 56), não sendo, jamais, ponto de partida, mas, sim, incômoda influência contra a qual o autor deveria lutar. Aceitando a inexistência de um "pensamento estético universal" (MELO NETO, 1997, p. 56) para sua época, Cabral observava como essas tendências pessoais tornam-se poderosas e acentuam a polarização entre as ideias de inspiração e trabalho de arte, fazendo com que a sua defesa ou condenação se justifique em nome do mesmo princípio:

É em nome da expressão, e para lográ-la, que se valoriza a escrita automática e é ainda em nome da expressão pessoal que se defende a absoluta primazia do trabalho intelectual na criação, levado a um ponto tal que o próprio fazer passa a justificar-se por si só, e torna-se mais importante do que a coisa a fazer (MELO NETO, 1997, p. 56).

Para quem o objeto de arte, desde priscas eras, constituía elemento de preocupação permanente, a crítica de Cabral ao próprio fazer como algo mais valorizado que o resultado deste fazer, de algum modo vai de encontro a certa crítica que, Ihe evidenciando o hermetismo de cunho cerebral, tende a ignorar a riqueza estética e comunicacional de seus versos, sem necessidade de misticismo acadêmico, disfarçado, outrossim, de certo pedantismo.

A defesa desses extremos - inspiração e o trabalho de arte - conduz, segundo Cabral, a um único caminho na tentativa, ainda, de conceituar composição: partir da consideração dos fatores pessoais. Será a maneira pessoal de trabalhar de cada artista que determinará o conceito de composição e, mesmo, de poema. Nessa constatação, mais do que criticar o jovem autor, Cabral procura, em verdade, apenas 
sublinhar o que the parece uma inevitabilidade de época, a qual lança-se todo aquele que, por motivos diversos, alça-se ao exercício da escrita:

Libertado da regra, que the parece, e com razão, perfeitamente sem sentido, porque nada parece justificar a regra que propõem as academias, o jovem autor começa a escrever instintivamente, como uma planta cresce. Naturalmente, ele será ou não um homem tolerante consigo mesmo, e esse homem que existe nele vai determinar se o autor será ou não um autor rigoroso, se pensará em termos de poesia ou em termos de arte, se se confiará à sua espontaneidade ou se desconfiará de tudo o que não tenha submetido antes a uma elaboração cuidadosa (MELO NETO, 1997, p. 56).

Marcos Siscar, destacando que a crítica de Cabral à dimensão personalista em poesia dava-se em paralelo com o propósito da relação com o público, irá observar que:

[...] uma poesia cujo interesse se limita à vida do poeta é uma poesia em que a dimensão coletiva do efeito literário sai prejudicada. Ela soa imediatamente como mero relato de uma experiência individual, como relação parcial e interessada, desvinculada de uma ambição de ordem histórica e artística; não atende à necessidade social à qual idealmente se destina. Ou seja, enquanto permanece na esfera do individualismo, não está à altura de sua tarefa criadora do sentido comum que, em Cabral especificamente, liga-se à ideia de atendimento à demanda do público." (SISCAR, 2018, p. 613)

Ao iniciar sua escrita, esse jovem autor, liberto de regras, porque inexistentes, não encontrará, segundo Cabral, no "espetáculo da sociedade", sua matéria de poesia, para ele confusa. Será, sobretudo, no "espetáculo da literatura" que esse aprendiz de poeta fundará sua poesia. "O confrade lhe é mais real do que o leitor", pois que mais amistoso, já que é nesse "espetáculo da vida literária" que outros autores justificarão todas as suas inclinações pessoais: haverá, continua ele, "críticos para teorizar sobre sua preguiça ou sua minúcia obsessiva, grupos de artistas com que identificar-se a partir de cujo gosto condenar todo o resto" (MELO NETO, 1997, p. 57). Nesse ponto, Cabral identifica, no jovem escritor, a descoberta de uma "literatura pessoal", com a qual desbravará todos os caminhos à revelia de tudo aquilo que não lhe for espelho. Há, nesse sentido, certa cronologia com a qual Cabral propõe identificar o caminho percorrido por estes autores:

Primeiro, o jovem autor vai procurando-se entre os autores de seu tempo, identificando-se primeiro com uma tendência, depois com um 
pequeno grupo já de orientação bem definida, depois com o que ele considera o seu autor, até o dia em que possa dar expressão ao que nele é diferente também desse seu autor. É então neste momento, em que depois da volta ao mundo se redescobre com uma nova consciência, a consciência do que o distingue, do que nele é autêntico, consciência formada à custa da eliminação de tudo o que ele pode localizar dos outros, que o jovem autor pensa ter desencavado aquele material especialíssimo, e exclusivo, com que construir a sua literatura (MELO NETO, 1997, p. 57).

Embora o percurso possa ser o mesmo para poetas fáceis e difíceis, Cabral continua vendo impossibilidade quanto a um "tipo ideal de composição" para o poema moderno. Será somente na polarização definida pelas ideias opostas de inspiração e trabalho artístico que o autor limitará sua possibilidade de estudo, ou seja, nos pontos mais extremos dessa polarização é que se organizarão as ideias sobre composição. Ele observa, ainda, que mesmo as ideias de inspiração e trabalho de arte não possuem apenas um conceito. Escreve:

A inspiração será identificada por uns como uma presença sobrenatural - literalmente - e a inspiração pode ser localizada por debaixo das justificações científicas para o ditado absoluto do inconsciente. Trabalho de arte pode valer a atividade material e quase de joalheria de construir com palavras pequenos objetos para adorno das inteligências sutis e pode significar a criação absoluta, em que as exigências e as vicissitudes do trabalho são o único criador da obra de arte (MELO NETO, 1997, p. 57).

Partindo, portanto, dessa constatação, ao que nos parece, limitadora do sentido de composição no poema moderno, filha desse "extremo" surgido entre poetas fáceis - para os quais o poema advém da inspiração - e os poetas difíceis - para os quais o poema é o resultado de um trabalho de arte - Cabral procurou esboçar as ideias que, a seu ver, prevaleciam sobre composição naqueles primeiros anos da década de 1950.

\section{Os poetas fáceis}

Na família dos primeiros poetas, os fáceis, Cabral destacará que "o trabalho artístico é superficial". Esse julgamento provém da constatação de que, para esses autores que aceitam a inspiração como força motriz de seu trabalho, o poema, via de regra, representa uma experiência direta, sendo-o, muitas vezes, apenas o registro 
imediato dessa experiência. O poema simplesmente "traduz, transcreve, transmite" a experiência, qualificando, nesses casos, o poeta como um simples "transmissor de poesia". Outra característica apontada por Cabral para essa "experiência" poética é o fato dela ser única, ou seja, "ela ou é expressada no poema, confessada por meio dele, ou desaparece". A necessidade de poesia para esses poetas é consequência, segundo Cabral, de um "estado de exaltação (ou de depressão), que o compele à escrita, [e] nunca advém de um tema objetivo ou exterior". Como resultado, os poemas são, em sua maioria, de um corte preciso, seja no tempo, seja no assunto, jamais abordado de forma completa e sistemática por este ou qualquer outro poema, pois, como já dissemos, trata-se do fruto de uma experiência única. Talvez, por isso mesmo, sejam poemas que se limitam ao "retoque posterior ao momento da criação", visto que, "quase nunca esse retoque vai além da mudança de uma expressão ou de uma palavra, jamais atingindo o ritmo geral ou a estrutura do poema" (MELO NETO, 1997, p. 58). Para Cabral, as críticas que, em geral, se empregam contra tais poetas, desqualificando-os de preguiçosos, incapazes e com falta de gosto artístico, são injustas. Posto que, para esses poetas, o contrário desses defeitos não é tido por qualidade, pois "eles jamais pretendem criar um objeto artístico, capaz de provocar no leitor um efeito previsto e perfeitamente controlado pelo criador" (MELO NETO, 1997, p. 58). Os poetas fáceis creditam somente à fidelidade da experiência o interesse de seu público, que, ao "passarem" pelo poema, também poderão senti-la tal qual ocorrera com o próprio autor. Nesse sentido, não Ihes interessa a elaboração do texto, que poderia distorcer a experiência vivida, fazendo com que o leitor não a percebesse. Em resumo:

(...) a existência objetiva do poema, como obra de arte, não tem sentido para ele. O poema é um depoimento e quanto mais direto, quanto mais próximo do estado que o determinou, melhor estará. A obra é um simples transmissor, um pobre transmissor, o meio inferior que ele tem de dar a conhecer uma pequena parte da poesia que é capaz de vir habitá-lo (MELO NETO, 1997, p. 59).

Evidentemente, Cabral sabia bem que essa poesia na qual "o autor é tudo" tendia a atingir mais facilmente o leitor. Apontava ele dois motivos principais para isso: primeiro, uma "escrita em linguagem corrente", que por ser "pouco elaborada ela desdenha completamente os efeitos formais e tudo o que faça apelo ao esforço e à inteligência"; trata-se de uma poesia de "tom essencial", que privilegia suas qualidades 
"musicais" em detrimento das "intelectuais ou plásticas", onde a "entonação" se sobrepõe às "palavras". Reforçando o caráter fácil com que essa poesia chegaria ao leitor, ou melhor, passaria por ele, como Cabral sentencia:

É uma poesia que se lê mais com a distração do que com a atenção, em que o leitor mais desliza sobre as palavras que as absorve. Vagamente, para captar das palavras, sua música. E uma poesia para ser lida mais do que para se relida" (MELO NETO, 1997, p. 59-60, grifos nossos).

Embora Cabral não os defina assim, é possível pensar numa fórmula simples em que estabeleçamos que aos poetas fáceis tendem leitores fáceis. Leitores em que a preocupação de leitura assemelha-se à de escrita dos seus poetas preferidos, qual seja: a experiência. Sentir a "alma do poema", passando por ele, como em ritmo de música, sem esforço reflexivo e questionamentos, apenas aceitação e deleite.

Considerando que essa família de poetas dominava a cena contemporânea a Cabral, este apontará, como consequência à literatura nacional certo "desprezo considerável pelos aspectos propriamente artísticos da poesia" (MELO NETO, 1997, p. 59). Nessa poesia, de alcunha fácil, "todos os recursos de que a inteligência ou a técnica [podem] servir-se para intensificar a emoção, [são deixados] de lado" (MELO NETO, 1997, p. 60). Não há sentido algum de trabalho artístico, como sugere Cabral, de algo que busque uma reação esperada em seu leitor, com proporção e objetivo: "toda interferência intelectual lhe parece baixa interferência humana naquilo que imagina quase divino" (MELO NETO, 1997, p. 60). É nesse sentido que não há, também, como se pressupõe um aspecto importante do trabalho artístico, desligamento do poema de seu criador. O poema não possui "vida independente", necessita, para ser compreendido, de referências posteriores à vida do autor e às circunstâncias da sua criação.

Ao leitor familiarizado com a poesia e o discurso de Cabral sobre sua poética, não é difícil perceber que a crítica que vem empregando até aqui aos poetas fáceis e seus poemas de inspiração divina, em verdade funciona como justificativa para a atitude poética que, naquele tempo, ele defendia e que o acompanhou por todos os livros e pela vida literária sui generis que construiu. É nesse aspecto que Cabral, ainda nesse raio- $X$ dos poetas fáceis, irá caracterizar a persona poética deles que, como vimos, quanto mais próxima dos poemas, melhor. Daí a observação de que, 
juntamente com suas obras, estes autores dão-se ao espetáculo, às vezes mais do que à própria obra. Tendo em vista que a "expressão de uma personalidade" é essencial para estas obras, o "indivíduo que escreve tende a suplantar em interesse a coisa escrita". A crítica nesse ponto é sem meias palavras:

\begin{abstract}
Está claro que nesse tipo de escritores vamos encontrar todos os adeptos da sinceridade e da autenticidade a qualquer preço, para quem essas palavras significam cinismo e deformação, vamos encontrar os mórbidos, os místicos, os invertidos, os irracionais e todas as formas de desespero com que um grande número de intelectuais de hoje fazem a sua profissão de descrença no homem (MELO NETO, 1997, p. 60).
\end{abstract}

Como consequência direta dessa "descrença no homem", ou seja, no trabalho intelectual em prol de uma realização estética, Cabral identifica, como particularidade da literatura brasileira, o fato de que, em sua maioria, os poetas esperam que o "poema aconteça, sem jamais forçá-lo a 'desprender-se do limbo'” (MELO NETO, 1997, p. 61), como sugerira Drummond. Isso criou, segundo ele, uma poesia bissexta, composta basicamente por poemas de circunstância. Cabe aqui, por força dos conceitos empregados, uma citação mais longa em que Cabral os define melhor:

\begin{abstract}
Esse conceito de circunstância geralmente põe em movimento as zonas mais limitadamente pessoais do poeta. A atitude deste é sempre a espera de que o poema se dê, de que se ofereça, com seu tema e sua forma. Essa atitude pode ser encontrada até nos poetas que mais conscientemente dirigem a escrita de seu poema. Eles dirigem seu poema, a feitura do poema, jamais se impõem o poema. O que desejam, e esperam, é o poema absolutamente necessário que se propõe com uma tal urgência que é impossível fugir-lhe. Isto poderia ser uma definição do poeta bissexto, em que as reservas de experiência parecem mínimas e que jamais pode encontrar em si mesmo o material com que construir os poemas que a necessidade do homem Ihe ordene (MELO NETO, 1997, p. 61).
\end{abstract}

Esta reserva em se impor o poema, em se impor um tema, um objetivo, e construir o seu poema, trabalhando-o artisticamente, criou, segundo Cabral, "certa repulsa ao sentido profissional da literatura", ou seja, para esses poetas que têm a inspiração como única fonte de poesia, existe a espera, não apenas de um "momento propício para realizar o poema", mas a espera de todo o poema, "com seu tema e sua forma". Para esses casos o "tema" e o "assunto" dos poemas são sempre o poema. São raros os casos de poemas sobre algum objeto e, quando ocorrem, "apenas 
[comunicam], do objeto, a visão subjetiva que o poeta se formou dele". Para justificar essa afirmação, Cabral relembra os nomes frequentes de poemas que se chamam: poema, ode, soneto, balada. Na mesma frequência, surge entre esses poetas $\mathrm{O}$ preconceito ao chamado "poeta por encomenda", que se impõe um tema e a partir dele realiza o seu trabalho. Para Cabral, não se trata de um preconceito contra a "possível baixeza, ou banalidade, ou por prosaísmo" dos temas propostos pelos poemas. A raiz primeira do problema está, como ele já vem chamando a atenção, no "desprezo pela atividade intelectual, essa desconfiança da razão do homem, essa ideia de que o homem apenas sabe quebrar as coisas superiores que lhe são dadas e que nada pode por si mesmo" (MELO NETO, 1997, p. 62).

Embora identifique na literatura moderna o maior desenvolvimento de uma "atomização" dos conceitos de arte e poesia - "não há uma arte, não há a poesia, mas há artes, há poesias" (MELO NETO, 1997, p. 62) - Cabral compreende que a responsabilidade maior sobre essa noção de poesia cabe ao Romantismo, posto que "com o deslocamento para o autor do centro de interesse da obra, as normas continuaram a existir, - mas somente até um ponto, até o ponto em que não prejudicam a expressão pessoal" (MELO NETO, 1997, p. 62). Cabral acusa aí o primeiro golpe às normas que, como consequência, erigiu o direito de cada poeta criar a sua norma particular, ao passo que "estilo", que na era clássica significava obediência às normas, com o Romantismo passa a definir "a maneira de cada autor interpretar essas normas consagradas" (MELO NETO, 1997, p. 63).

O poeta pernambucano percebia, portanto, na predominância dessas poéticas alimentadas pela inspiração e experiência, baseadas no individualismo e voltadas para o autor, tanto ou mais do que a obra, uma transformação que, invariavelmente, tendia ao "empobrecimento técnico", no qual o poeta não poderia praticar todas as experiências, pois, sua técnica seria "o domínio dos tiques particulares que constituem seu estilo", e não o domínio de uma ciência. Daí a característica da maioria dos livros de poesia como "coleções de pequenos poemas, cristalizações de momentos especiais, em que o trabalho formal se limita ao exercício do bom gosto" (MELO NETO, 1997, p. 62).

\section{Os poetas difíceis}


Nesse sentido, já direcionando sua crítica, também, aos poetas difíceis, Cabral, ainda sobre a ideia de "empobrecimento técnico", emitirá um alerta que, de alguma maneira, garante ao seu trabalho a dignidade de um olhar crítico justo, se considerarmos o quanto sua obra procurou romper com as tradições construídas pela primeira família de poetas:

Não se pode dizer que esse empobrecimento técnico não existe entre os membros dessa segunda família de espíritos, isto é, a daqueles que aceitam e procuram levar às últimas consequências o predomínio do trabalho de arte na composição literária. $\mathrm{Na}$ obra deles o empobrecimento é bastante visível. Porque se é verdade que o individualismo coloca o adepto da teoria da inspiração numa posição privilegiada para captar e dar expressão ao mais exclusivo e pessoal de si mesmo, é verdade também que coloca o adepto do trabalho de arte, como elemento preponderante, numa situação sem esperança, absolutamente irrespirável (MELO NETO, 1997, p. 64).

Entretanto, essa segunda atitude, para ele, é pouco frequente na literatura brasileira, em virtude, sobretudo, dos poucos poetas adeptos do trabalho de arte. Nos poetas difíceis, em oposição aos poetas adeptos da teoria da inspiração — "os filhos da improvisação" - , a origem do comportamento que aceita o predomínio do trabalho de arte está, muitas vezes, no "desgosto contra o vago e o irreal, contra o irracional e o inefável, contra qualquer passividade e qualquer misticismo, e muito de desgosto, também, contra o desgosto pelo homem e sua razão" (MELO NETO, 1997, p. 64). Esse aspecto, segundo Cabral, garante uma "melhor realização artística do poema" e pode fornecer do poeta que o escreve "uma imagem perfeitamente digna de ser que dirige sua obra e é senhor de seus gestos" (MELO NETO, 1997, p. 64-65). Essa posição mais ativa sobre o trabalho artístico, sem dúvida, é o que mais cativa Cabral em sua análise. Percebemos o quanto a orientação passiva de certos poetas com a realização epifânica de seus poemas o incomodava. Cabe aqui a descrição completa que Cabral faz do que, para ele, constitui um poeta difícil, pois, sabemos hoje, em alguma medida, é como se definisse a si:

Nestes poetas já o trabalho artístico não se limita ao retoque, de bom gosto e de boa economia, ao material que o instinto fornece. $O$ trabalho artístico é, aqui, a origem do próprio poema. Não é o olho crítico posterior à obra. O poema é escrito pelo olho crítico, por um crítico que elabora as experiências que antes vivera, como poeta. Nestes poetas, geralmente, não é o poema que se impõe. Eles se impõem ao poema, e o fazem geralmente a partir de um tema, 
escolhido por sua vez, a partir de um motivo racional. A escrita neles não é jamais pletórica e jamais se dispara em discurso. É uma escrita lacônica, a deles, lenta, avançando no terreno milímetro a milímetro. Estes poetas jamais encaram o trabalho de criação como um mal irremediável, a ser reduzido ao mínimo, a fim de que a experiência a ser aprisionada não fuja ou se evapore. $O$ artista intelectual sabe que o trabalho é a fonte da criação e que a uma maior quantidade de trabalho corresponderá uma maior densidade de riquezas. Quanto à experiência, ela não se traduz neles, imediatamente em poema. Não há por isso o perigo de que fuja. Eles não são jamais os possessos de uma experiência. Jamais criam debaixo da experiência imediata. Eles a reservam, junto com sua experiência geral da realidade, para um momento qualquer em que talvez tenham de empregá-la. Não será de estranhar que muitas vezes esqueçam essa experiência, como tal, e que ela, ao ressuscitar, venha vestida de outra expressão, diversa completamente (MELO NETO, 1997, p. 65).

À definição de poeta difícil podemos associar outra, posteriormente vinculada ao próprio Cabral, de poeta-crítico. Poeta que em todo o processo de criação mantém, como premissa, um rigoroso horizonte à sua obra. Para esse poeta, intelectual — para quem a racionalidade do trabalho é a fonte primeira da criação -, não é necessário — como aos poetas fáceis - "melhores momentos" para a criação, pois o seu trabalho "é a soma de todos os seus momentos melhores e piores", regido sempre pela imposição do poeta ao poema, nunca o contrário. Daí ser esse, o poema, nunca um corte num objeto ou mesmo um "aspecto particular de um objeto visto pela luz especial de um momento". Sobre esse exercício de imposição do poeta sobre o seu poema, Cabral realiza esse belo instantâneo:

Durante seu trabalho, o poeta vira seu objeto nos dedos, iluminandoo por todos os lados. E é ainda seu trabalho que lhe vai permitir desligar-se do objeto criado. Este será um organismo acabado, capaz de vida própria. É um filho, com vida independente, e não um membro que amputa, incompleto e incapaz de viver por si mesmo (MELO NETO, 1997, p. 66).

Entretanto, embora haja nos poetas difíceis essa capacidade de dar vida independente ao seu filho-poema, sem a necessidade de também ele, o poeta, darse ao espetáculo da vida literária como parâmetro para seu verso, Cabral demonstra que há nesses poetas tanta individualidade quanto nos poetas fáceis - "que aceitam cegamente o ditado de seu anjo ou de seu inconsciente" - , pois, quando criam seu poema, também criam o seu próprio gênero poético. $O$ que os diferencia é que, enquanto nos primeiros esse gênero é definido pela originalidade do homem, nos 
poetas difíceis essa definição se pauta pela originalidade do artista: "não é o tipo novo de morbidez que o caracteriza, mas o tipo novo de dicção que ele é capaz de criar" (MELO NETO, 1997, p. 66).

Essa capacidade do poeta difícil de criar uma nova dicção a partir da sua própria visão de gênero poético marca o início do desespero de sua situação, pois, por mais metódica que sejam as leis criadas em sua poética, não se lhe apresentam como um "catecismo para uso privado", que lhe ditará as ações seguintes. Vejamos como Cabral define esse "desespero" inicial que atinge o poeta difícil:

Ao escrever, ele não tem nenhum ponto material de referência. Tem apenas sua consciência, a consciência das dicções de outros poetas que ele quer evitar, a consciência aguda do que nele é eco e que é preciso eliminar, a qualquer preço. Com a ajuda que lhe poderia vir da regra preestabelecida ele não pode contar - ele não a tem. Seu trabalho é assim uma violência dolorosa contra si mesmo, em que ele corta mais do que se acrescenta, em nome ele não sabe muito bem de que (MELO NETO, 1997, p. 66).

O "desespero" de Cabral nos parece a "angústia” de Harold Bloom (2002). Tal qual o crítico inglês, Cabral identifica que somente na classe de poetas difíceis - os fortes para Bloom - a luta consigo e contra as dicções de seus precursores, via "violência dolorosa", poderá estabelecer aquilo que não é eco, aquilo que é original, não por ser feito de um homem, mas do esforço de um trabalho artístico de um homem. No entanto, e em função da tão reclamada falta de regras para o fazer do poema moderno, há, também, uma outra armadilha na qual o poeta difícil tem caído. Trata-se da "preponderância absoluta dada ao ato de fazer [que] termina por erigir a elaboração em fim de si mesma" (MELO NETO, 1997, p. 67). Independente dos seus resultados - das obras criadas - o trabalho se converte em exercício e passa a ter, para o poeta difícil, um valor em si, caminhando para o que Cabral chamará de "suicídio da intimidade absoluta" (MELO NETO, 1997, p. 67). A obra perde sua importância e passa a ser, apenas, um pretexto do trabalho, no qual o poeta procura todos os meios para que seu trabalho se faça mais demorado e difícil, impondo-se todas as barreiras formais possíveis; o poeta se regozija em ter "mais e mais resistências a vencer", mas a vitória aqui, para Cabral, nunca será da poesia, que, com esta subvalorização diante do fazer, também se encontra com outro tipo de incomunicação: a do balbucio. A tudo isso, recaía a possibilidade da "morte da comunicação" na poesia que, para Cabral, seria fruto da troca que os autores fizeram 
de um leitor definido - para o qual antes se escrevia, em função, como já foi dito, da sua necessidade - por um leitor possível, ou seja, aquele com o qual o autor possa se identificar em sua individualidade absoluta.

\section{A incomunicação dos poetas modernos}

Partindo da defesa do pressuposto de que a comunicação, antes fundamental à arte poética, tendia à morte com a consequência do poema moderno — seja produção de poetas fáceis ou difíceis - em isolar-se em si e no mundo narcísico ou intelectual do seu autor, Cabral fará uma longa defesa da importância que o leitor deveria exercer na "função moderna da poesia"2. Para ele, o papel do leitor seria o de contrapeso que agiria no controle para que ao poema fosse assegurada a comunicação. Noutro tempo, esse controle era exercido pela crítica que, a partir da necessidade do leitor, "de sua exigência definida pelo que esse leitor desejava encontrar na literatura de seu tempo" (MELO NETO, 1997, p. 68), definia os termos precisos e concretos desse desejo e pré-selecionava o cânone literário no qual o leitor poderia saciar sua necessidade. Mas isso não perturba o sono do poeta moderno, posto que "este tipo de poeta individualista, apenas dá de si" (MELO NETO, 1997, p. 68), pois sua escrita é como uma defesa contra o homem e a rua dos homens, "pois ele sabe que na linguagem comum e na vida em comum essa pequena mitologia privada se dissipará" (MELO NETO, 1997, p. 68). Longe dos seus, o poeta moderno tende ao esquecimento, à pobreza de uma incomunicação, como já foi dito. Cabral traça um perfil sintomático:

\footnotetext{
2 Esse foi o título dado por Cabral para sua "tese" apresentada no Congresso de Poesia de São Paulo, em 1954. Nele Cabral caminha pelo mesmo percurso apresentado em 1952, como evidencia este parágrafo: "Em consequência de não se terem fixado tipos de poemas capazes de corresponderem às exigências da vida moderna, o poeta contemporâneo ficou limitado a um tipo de poema incompatível às condições da existência do leitor moderno, condições a que este não pode fugir. A apresentação (não organizada em formas 'cômodas' ao leitor) de sua, rica embora, matéria poética faz da obra lazeres e recolhimento difíceis de serem encontrados nas condições da vida moderna. Cada tipo de poema que conheceu a literatura antiga nasceu de uma função determinada; ajustar-se às exigências da estrutura perfeitamente definida do poema era, para o poeta, adaptar-se sua expressão poética às condições em que ela poderia ser compreendida e, portanto, corresponder às necessidades do leitor. O poema moderno, por não ser funcional, exige do leitor um esforço sobre humano para se colocar acima das contingências de sua vida. O leitor moderno não tem ocasião de defrontar-se com a poesia nos atos normais que pratica durante sua vida diária. Ele tem, se quer encontrá-la, de defender dentro de seu dia um vazio de tempo em que possa viver momentos de contemplação, de monge ou de ocioso" (MELO NETO, 1997, p. 98-99).
} 
Este poeta não quer receber nada nem compreende que sua riqueza só pode ter origem na realidade. Na sua literatura existe apenas uma metade, a do criador. A outra metade, indispensável a qualquer coisa que se comunica, ele a ignora. Ele se julga a parte essencial, a primeira, do ato literário. Se a segunda não existe agora, existirá algum dia - e ele se orgulha de escrever para daqui a vinte anos. Mas ele esquece o mais importante. Nessa relação o leitor não é apenas o consumidor. O consumidor é, aqui, parte ativa. Pois o homem que lê quer ler-se no que lê, quer encontrar-se naquilo que ele é incapaz de fazer (MELO NETO, 1997, p. 68-69).

Ainda saudosista de outras épocas, em que reinava o equilíbrio entre inspiração e trabalho de arte em prol das necessidades de comunicação com seu leitor, Cabral pondera que o poeta não se sentia violado em sua sensibilidade ao se impor um tema que fosse "ditado pela necessidade da vida diária dos homens" (MELO NETO, 1997, p. 69), pois, nessas épocas, tanto a inspiração quanto o trabalho de arte estavam, também, subordinados às necessidades da comunicação.

Ao fim, Cabral apresenta a definição da função da "regra" para aquilo que ele via, não como um limitador da tão aclamada liberdade do poeta, mas como algo fundamental para garantir ao poema o valor que a seu tempo fosse compreensão universal entre os homens:

As regras nessas épocas não são obedecidas pelo desgosto da liberdade, que segundo algumas pessoas é a condição básica do poeta. A regra não é a obediência, que nada justifica, as maneiras de fazer defuntas, pelo gosto do anacronismo, ou as maneiras de fazer arbitrárias, pelo gosto do malabarismo. A regra é então profundamente funcional e visa assegurar a existência de condições sem as quais o poema não poderia cumprir sua utilidade. Para o poeta ela não é jamais uma mutilação, mas uma identificação. Porque o verdadeiro sentido da regra não é o de cilício para o poeta. O verdadeiro sentido da regra está em que nela se encorpa a necessidade da época (MELO NETO, 1997, p. 70).

É salutar perceber a preocupação de Cabral com a "utilidade" do poema. Sobretudo com um olhar de hoje, em que outros aspectos, além da própria vida do poeta, também foram inseridos, por muitos leitores, na "experiência" da leitura de poemas. Qual seria a necessidade da época atual, ávida por leituras cada vez mais apressadas do mundo, em relação à poesia? Passados mais de meio século desses apontamentos críticos de Cabral, fica a sensação de que esse tema, poesia e composição, nunca se esgota. Mas, talvez, a maior lição, sobretudo aos candidatos a 
poeta ou a crítico literário, seja a constante preocupação demostrada, por um dos maiores poetas brasileiros, com o leitor.

\section{Conclusão}

As palavras de Cabral, embora aqui se ocupem numa busca - por ele mesmo julgada impossível — de um conceito de composição para o poema moderno, não são de difícil vinculação às palavras de Harold Bloom, na sua busca por uma teoria da influência poética. Se para Cabral podemos dividir os poetas em duas famílias: os fáceis e os difíceis, para o crítico inglês a divisão dar-se-ia entre os fracos e os fortes. Considerando que, na definição de Bloom, os poetas fortes são "grandes figuras com a persistência de lutar com seus precursores, mesmo até a morte" (BLOOM, 2002, p. 55) e que os fracos são aqueles que "idealizam", a semelhança, respectivamente, com os poetas difíceis e fáceis de Cabral nos parece evidente. Quem mais, senão um "autor rigoroso", preocupado com uma "elaboração cuidadosa" de sua obra para assumir o posto de forte frente aos seus precursores? E, em ponto oposto, que melhor definição do que fraco, para aquele "homem tolerante" que confia mais em sua "espontaneidade" do que na luta com palavras; que credita à inspiração sua glória? Se, no rigor dos dicionários, as palavras - forte - difícil / fraco - fácil - não se assumem como sinônimos, ao pensarmos os caminhos percorridos em separado por João Cabral e Harold Bloom, cada um em sua busca particular, tendemos a identificar uma preocupação comum com o destino da poesia. Cabral, preocupado com o risco iminente da perda de comunicação em função de uma poesia voltada mais para a necessidade do autor do que do leitor, de alguma maneira vincula-se à crítica que Bloom empregou contra o "reducionismo cultural" ao qual a literatura fora lançada com o advento dos Estudos Culturais. No caso de Cabral, é pertinente observar que sua defesa da ideia de regras para a realização poética pautava-se justamente na possibilidade de que, com tal medida, os leitores e críticos pudessem mais facilmente distinguir entre os diversos textos aqueles cuja realização atendiam uma necessidade de uma época. Sem entrar no mérito das questões de mercado e consumo que regem, também, gosto e predileções, tendemos a concordar com as visões de Cabral e Bloom e concluir, ao nosso modo, que, a favor da exigência e existência de uma necessidade de época por determinada literatura, pensarmos que aspectos da ordem da qualidade, do rigor e da comunicação não podem ser abandonados em favor do simples 
comunicar. A questão não seria, portanto, de pérolas aos poucos, como canta o crítico, mas, como vociferava o poeta modernista, biscoito fino às massas.

\section{Referências}

ATHAYDE, Félix de. Idéias fixas de João Cabral de Melo Neto. Rio de Janeiro: Nova Fronteira, FBN; Mogi das Cruzes: Universidade de Mogi das Cruzes, 1998.

BLOOM, Harold. A angústia da influência. 2. ed. Rio de Janeiro: Imago Ed., 2002.

CARVALHO, Ricardo Souza de. Do catalão ao português: João Cabral tradutor. Revista de Letras. São Paulo, v.49, n.1, p.137-149, jan./jun. 2009. Disponível em $<$ https://periodicos.fclar.unesp.br/letras/article/view/1754/1429> Acesso em: 01 jun. 2021.

LIMA, Luiz Costa. João Cabral: poeta crítico. In.: LIMA, Luiz Costa. Intervenções. São Paulo: Edusp, 2002.

MELO NETO, João Cabral de. Da função moderna da poesia. In.: MELO NETO, João Cabral de. Prosa. Rio de Janeiro: Nova Fronteira, 1997. p. 97-101.

MELO NETO, João Cabral de. Poesia e composição. In.: MELO NETO, João Cabral de. Prosa. Rio de Janeiro: Nova Fronteira, 1997. p. 51-70.

SISCAR, M. João Cabral e a poesia contemporânea: o drama da destinação. Texto Poético, [S. I.], v. 14, n. 25, p. 610-616, 2018. DOI: 10.25094/rtp.2018n25a527. Disponível em: https://textopoetico.emnuvens.com.br/rtp/article/view/527. Acesso em: 5 jun. 2021. 